\title{
EQUITY
}

Vol. 24, No.2, 2021, 141-156

DOI: 10.34209 /equ.v24i2.2468

P-ISSN 0216-8545 | E-ISSN 2684-9739

Diunggah : Januari 2021

Diterima : September 2021

Dipublikasi : Januari 2022

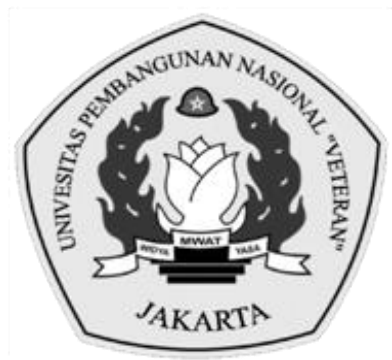

\section{PERAN SDM DAN TEKNOLOGI INFORMASI PADA PENERAPAN STANDAR AKUNTANSI PEMERINTAHAN BERBASIS AKRUAL}

\author{
Galan Nur Subhi ${ }^{*}$, Indrawati Yuhertiana ${ }^{2}$ \\ 19alansubhi@gmail.com, ${ }^{2}$ yuhertiana@upnjatim.ac.id \\ 1,2Universitas Pembangunan Nasional "Veteran" Jawa Timur \\ *Penulis Korespondensi
}

\begin{abstract}
Abstrak
Studi ini bertujuan untuk menganalisa peran kompetensi Sumber Daya Manusia (SDM) dan pemanfaatan Teknologi Informasi (TI) pada penerapan Standar Akuntansi Pemerintahan berbasis akrual sebagai bentuk transparansi dan akuntabilitas pada era reformasi di Indonesia. Penelitian ini menggunakan metode tinjauan literatur yang merupakan cara untuk mengidentifikasi, mengevaluasi, dan menafsirkan penelitian yang telah tersedia dan relevan dengan bidang atau topik tertentu. Berkembangnya tuntutan terhadap akuntabilitas dan juga kinerja pemerintah daerah menuntut pemerintah untuk menyajikan laporan keuangan secara akuntabel dan transparan dengan menggunakan basis akuntansi akrual. Penerapan basis akrual secara optimal dapat terwujud dengan didukung oleh sumber daya manusia dengan kompetensi memadai dan pemanfaataan teknologi informasi yang optimal agar penyajian laporan keuangan yang dihasilkan efektif dan efisien. Hasil studi ini menyatakan pentingnya peran pelatihan, bimbingan teknis, relevansi pendidikan, serta masa kerja untuk meningkatkan kompetensi SDM, serta tersedianya perangkat keras, perangkat lunak, dan jaringan internet untuk menunjang pemanfaatan teknologi informasi dalam penerapan SAP berbasis akrual.
\end{abstract}

Kata Kunci: Standar Akuntansi Pemerintahan; Basis Akrual; Sumber Daya Manusia; Teknologi Informasi

\begin{abstract}
The Aim of this study is to analyze the role of human resource competence (HR) and the use of Information Technology (IT) in the application of accrual-based Government Accounting Standards as a form of transparency and accountability in the reform era in Indonesia. This study uses the literature review method to identify, find, and research what is available and relevant to a particular field or topic. The demand for accountability and performance of local governments requires the government to provide financial reports in an accountable and transparent orientation using the accrual basis. The optimal application of the accrual basis can be realized with the support of Human Resources with adequate competence and the optimal use of information technology in order to make effective and efficient financial statements. The results of this study state the importance of training, technical guidance, relevance of education, and tenure to support HR competencies, as well as the availability of hardware, software, and internet networks to support the use of information technology in government accounting standard accrual-based implementation.
\end{abstract}

Keywords: Government Accounting Standards; Accrual Basis; Human Resource; Information Technology 


\section{PENDAHULUAN}

Krisis keuangan yang berlangsung di Indonesia telah memengaruhi permintaan publik terhadap transparansi dalam investasi, persaingan terbuka, dan kepercayaan pada akuntabilitas sektor swasta maupun sektor publik. Berbagai sektor melakukan reformasi yang mengakibatkan beberapa perubahan besar termasuk di sektor keuangan nasional. Reformasi besar ini ditandai dengan banyaknya regulasi baru terkait penyempurnaan pengelolaan keuangan negara (Yuhertiana, 2015). Salah satu reformasi yang dijalankan berupa kewajiban Pemerintah Pusat serta Pemerintahan Daerah dalam menerapkan SAP pada setiap instansi pemerintahan dengan berbasis akrual, yang mulai diterapkan secara penuh pada tahun 2015 (L. D. S. Dewi et al., 2017; Kristiawati, 2015; Permana \& Wiratmaja, 2016). Kemajuan Standar Akuntansi Pemerintahan berbasis akrual di Indonesia ditandai dengan adanya reformasi di sektor keuangan dengan hadirnya UndangUndang No. 17 Tahun 2003 tentang Keuangan Negara, Undang-Undang Nomor 1 tahun 2004 tentang Perbendaharaan Negara, dan Undang-Undang Nomor 15 tahun 2004 tentang Pemeriksaan Pengelolaan dan Tanggung Jawab Keuangan Negara. Berdasarkan peristiwa tersebut, maka muncul Peraturan Pemerintah No. 24 tahun 2005 tentang Standar Akuntansi Pemerintahan berbasis kas menuju akrual yang kemudian diperbaharui dengan diterbitkannya Peraturan Pemerintah Nomor 71 tahun 2010 tentang Standar Akuntansi Pemerintahan Berbasis Akrual .

Pada akuntansi berbasis akrual, pencatatan transaksi disesuaikan dengan waktu terjadinya aliran sumber daya, sehingga informasi yang menyeluruh dapat disajikan, karena akuntansi berbasis akrual merupakan basis akuntansi yang mengakui, mencatat, dan melaporkan setiap transaksi ekonomi dan peristiwa lainnya ke dalam laporan keuangan atas, tanpa adanya pertimbangan waktu kas atau setara kas dibayarkan atau diterima (Asfiansyah, 2015; Hastutik \& Riduwan, 2018). Dengan diterapkannya basis akrual pada akuntansi pemerintahan diharapkan kinerja instansi pemerintah dalam penyusunan maupun realisasi anggaran dapat diperbaiki (L. K. U. Dewi et al., 2018).

Keberhasilan penerapan Standar Akuntansi Pemerintahan berbasis akrual dipengaruhi oleh beberapa faktor, di antaranya yaitu sumber daya manusia yang berkompeten dan pemanfaatan teknologi informasi (Pattiasina \& Noch, 2019). Sumber daya manusia dalam suatu organisasi merupakan aset yang sangat bernilai, karena kesuksesan suatu organisasi tergambar dari kualitas sumber daya manusia yang menjalankan perannya. Jika suatu organisasi dapat mendukung pengembangan karir pegawai dengan menilai kemampuannya, maka pegawai selaku sumber daya manusia akan melakukan tugasnya dengan sebaik-baiknya. Pengembangan kompetensi sumber daya manusia melalui orientasi kompetensi akan memengaruhi tingkat produktivitas instansi pemerintah, sehingga kinerja yang diharapkan dapat menguntungkan dan memuaskan masyarakat (Hastutik \& Riduwan, 2018).

Untuk dapat menyajikan informasi keuangan yang bermanfaat untuk para pengguna, maka dibutuhkan pegawai dengan kompetensi yang mumpuni dan sistem akuntansi serta teknologi informasi yang memadai. Latar belakang pendidikan yang relevan, intensitas pelatihan, dan ketrampilan merupakan cerminan dari kompetensi yang dimiliki oleh SDM. Penelitian yang dilakukan oleh 
Putra \& Ariyanto (2015), serta L. D. S. Dewi et al. (2017)) menyebutkan bahwa kompetensi sumber daya manusia berpengaruh positif signifikan terhadap keberhasilan penerapan penerapan akuntansi berbasis akrual. Diperlukan komitmen dan keseriusan dari Pemerintah Pusat dan Pemerintah Daerah dalam menyusun perencanaan SDM yang terdapat di Instansi Pemerintah. Termasuk memberlakukan sistem insentif yang layak dalam upaya meminimalisir potensi terjadinya kecurangan oleh SDM yang berkaitan langsung dengan akuntansi pemerintahan (Wijayanti \& Handayani, 2017).

Dalam penerapannya, kurangnya persiapan aparatur pemerintah dan kurangnya pemahaman tentang standar pelaporan keuangan menjadikan kegiatan pendidikan serta pelatihan sebagai upaya pemerintah untuk mengatasi kesulitan dalam penyusunan laporan keuangan (Jantong et al., 2019; Yusrisal, 2020). Hal ini sejalan dengan Peraturan Pemerintah No.101 tahun 2000 tentang Pendidikan dan Pelatihan Pegawai Negeri Sipil yang menyebutkan bahwa salah satu upaya untuk meningkatkan kompetensi Pegawai Negeri Sipil adalah dengan melaksanakan penyelenggaraan program pendidikan dan pengangkatan dalam jabatan.

Selain faktor sumber daya manusia, keberhasilan penerapan SAP berbasis akrual dan kualitas informasi yang tersaji pada laporan keuangan Instansi pemerintah juga dipengaruhi oleh tingkat pemanfaatan teknologi informasi. Teknologi informasi digunakan sebagai metode untuk menyajikan informasi yang berkualitas tinggi, relevan, efektif dan efisien, yang digunakan baik untuk keperluan individu, perusahaan maupun pemerintah dan merupakan informasi strategis dalam pengambilan keputusan. Teknologi informasi memanfaatkan sekumpulan komputer untuk proses pengolahan data, sistem jaringan menghubungkan antar komputer sesuai kepentingan, dan menggunakan teknologi telekomunikasi agar informasi dapat disebarluaskan dan diakses dalam skala global.

Pemanfaatan teknologi informasi pada Pemerintah Pusat dan Pemerintah Daerah telah ditetapkan dalam Pasal 13 Peraturan Pemerintah Nomor 56 Tahun 2005 tentang Sistem Informasi Keuangan Daerah menggantikan Peraturan Pemerintah Nomor 11 Tahun 2001 tentang Sistem Informasi Keuangan Daerah. Laju perkembangan teknologi informasi saat ini sangat cepat, sehingga diharapkan dengan adanya teknologi informasi ini pemerintah dapat memperbaiki dan meningkatkan kualitas pengelolaan keuangan daerah dan memperbaiki kualitas informasi keuangan daerah yang diberikan kepada masyarakat. Teknologi informasi akan sangat berkontribusi dalam penerapan standar akuntansi pemerintahan berbasis akrual, banyaknya jumlah transaksi jika dilakukan secara manual akan meningkatkan risiko terjadinya kesalahan pencatatan. Oleh karena itu, penggunaan teknologi informasi yang tepat akan mendukung pemerintah dalam memproses transaksi keuangan dengan efektif dan efisien dalam penyusunan laporan keuangan (Satrio et al., 2016). Penelitian yang dilakukan oleh Armaini (2017), Binawati \& Susliyanti (2020), Niagawan et al. (2020) menyatakan bahwa pemanfaatan teknologi informasi berpengaruh positif signifikan terhadap keberhasilan penerapan SAP berbasis akrual. 


\section{TINJAUAN PUSTAKA}

\section{Kompetensi Sumber Daya Manusia}

Penerapan basis akrual dapat diterapkan dengan optimal jika Sumber Daya Manusia yang ada memiliki kompetensi yang mumpuni. Kompetensi merupakan kapasitas keahlian untuk melakukan atau melaksanakan pekerjaan. Jika pegawai yang melakukan pekerjaan tidak memiliki kompetensi yang memadai maka kinerja maksimal dalam pekerjaannya sangat sulit untuk dicapai, hal ini karena kompetensi sumber daya manusia yang tidak kompeten seringkali tidak memedulikan reformasi (Yanni et al., 2020). Dengan kompetensi SDM yang berkualitas maka efisiensi dapat ditingkatkan, sehingga penyusunan laporan keuangan dapat selesai tepat waktu. Hal ini dikarenakan SDM tersebut memiliki pemahaman dasar dan latar belakang pengetahuan tentang hal-hal yang harus diselesaikan, sehingga dapat menyajikan laporan keuangan secara efektif dan efisien, karena semakin berpengetahuan sumber daya manusia tersebut maka semakin kuat tanggung jawab dan berkompetisi dalam memenuhi kewajibannya (Indrawati, 2018), termasuk di antaranya kemampuan sumber daya manusia untuk menerapkan pengetahuan dan keterampilan tersebut dalam kondisi yang baru.

\section{Pemanfaatan Teknologi Informasi}

Teknologi informasi tidak hanya melibatkan perangkat lunak dan perangkat keras (software dan hardware) yang dibutuhkan dalam mengolah dan menyimpan informasi, tetapi juga memiliki fungsi untuk mendistribusikan informasi. Pemanfaatan teknologi informasi tercermin dari tingkat integrasi teknologi informasi pada tugas-tugas akuntansi yang dilaksanakan (Wardani \& Andriyani, 2017). Tingkat pemanfaatan teknologi dapat tercermin dari frekuensi pemakaian dan jumlah software yang digunakan. Pemanfaatan teknologi informasi secara optimal dengan didukung oleh kompetensi pegawai yang menggunakannya dapat mendukung pelaporan keuangan yang efektif dan efisien, karena teknologi informasi memiliki manfaat yaitu mempercepat proses transaksi, akurasi lebih baik dalam penghitungan, penyimpanan data dengan jumlah besar, dan kemampuan multiprocessing (Iznillah et al., 2015).

\section{Standar Akuntansi Pemerintahan}

Budiono (2016) menyatakan bahwa standar akuntansi pemerintahan merupakan kualifikasi yang memiliki legal force yang dapat meningkatkan kualitas laporan keuangan pemerintah Indonesia. Sedangkan menurut Sinaga (2005) standar akuntansi pemerintahan merupakan pedoman untuk menyeragamkan opini antara penyusun, pengguna laporan keuangan, serta auditor. Dengan harapan dapat dimanfaatkan sebagai media komunikasi antara pemerintah dan para stakeholder, sehingga keuangan negara dapat dikelola dengan akuntabel dan transparan.

\section{Standar Akuntansi Pemerintahan Berbasis Akrual}

Berdasarkan PP No. 71 tahun 2010 pasal 1 ayat 8 tentang standar akuntansi pemerintahan, SAP Berbasis Akrual adalah Standar Akuntansi Pemerintahan yang mengakui pendapatan, beban, aset, utang, dan ekuitas dalam pelaporan finansial 
berbasis akrual, serta mengakui pendapatan, belanja dan pembiayaan dalam pelaporan pelaksanaan anggaran berdasarkan basis yang ditetapkan dalam APBD (Ranuba et al., 2015). Komponen laporan keuangan berdasarkan PP No.71 tahun 2010 terdiri dari Laporan Realisasi Anggaran, Laporan Perubahan Saldo Anggaran Lebih, Neraca, Laporan Arus Kas, Laporan Operasional, Laporan Perubahan Ekuitas, dan Catatan atas Laporan Keuangan.

\section{METODOLOGI PENELITIAN}

Metode yang digunakan pada penulisan artikel ini menggunakan pendekatan literature review (tinjauan literatur). Literature review merupakan sebuah studi yang merangkum dan mensintesis penelitian sebelumnya tentang sebuah topik tertentu (Andiola et al., 2017). Penelitian literature review berisi ulasan, rangkuman, serta pemikiran penulis dengan melakukan peninjauan berbagai dokumen baik internasional maupun nasional, seperti publikasi akademis, publikasi pemerintah, UU dan peraturan, jurnal, buku, media berita, dan bentuk catatan lain yang relevan dengan topik yang dibahas (Yuhertiana, 2015; Massaro et al., 2016). Tujuan akhir dari metode tinjauan literatur yaitu agar memperoleh deskripsi detail yang berhubungan dengan sesuatu yang orang atau peneliti lain sudah kerjakan. Proses dalam melakukan sebuah tinjauan literatur, pada umumnya dibagi menjadi 3 tahap utama yaitu planning, conducting dan reporting (Santis et al., 2018; Zhu et al., 2018). Maka dari itu, metodologi penelitian yang diterapkan dalam studi ini didasarkan pada langkah-langkah yang terstruktur dan tersusun.

Tahap pertama yang harus dilakukan yaitu planning (perencanaan). Artikel ini bertujuan untuk memberikan gambaran, deskripsi, ringkasan, dan evaluasi kritis terhadap peran kompetensi sumber daya manusia dan pemanfaatan teknologi informasi dalam penerapan Standar Akuntansi Pemerintahan berbasis akrual pada instansi-instansi pemerintah di Indonesia melalui survei terhadap artikel ilmiah, jurnal/prosiding, dan literatur Iain berdasarkan bidang penelitian atau teori tertentu sehingga dapat berkontribusi dalam memahami peran kompetensi sumber daya manusia dan penggunaan teknologi informasi dalam pelaksanaan reformasi akuntansi sektor publik.

Tahap yang kedua yaitu conducting (melakukan review). Peneliti perlu mencermati relevansi setiap literatur yang digunakan, lalu perlu adanya ketentuan dalam melakukan seleksi sumber data, bagaimana proses dalam ekstraksi dari data yang didapat, bagaimana cara mengkaji, dan melakukan sintesis sumber data agar memperoleh hasil review yang memuaskan. Jenis data dalam penelitian ini yaitu jenis data sekunder, karena semua data bersumber dari internet sehingga tidak dikumpulkan secara langsung

Pencarian literatur dalam penelitian ini dimulai dengan memilih artikel dari database elektronik bereputasi seperti Google Scholar, Garda Rujukan Digital (Garuda Ristekbrin), dan situs resmi Perpustakaan Nasional Republik Indonesia dengan menggunakan kata kunci "Standar Akuntansi Pemerintahan", "Basis akrual", "Kompetensi Sumber Daya Manusia”, dan "Pemanfaatan Teknologi Informasi”. Hasil penelusuran tersebut menemukan 591 artikel penelitian dari jumlah total masing- 
masing database yang membahas tentang kompetensi sumber daya manusia dan pemanfaatan teknologi informasi pada penerapan akuntansi berbasis akrual.

Tabel 1. Jumlah Hasil Pencarian Literatur

\begin{tabular}{clcccccc}
\hline \multirow{2}{*}{ No } & \multirow{2}{*}{ Database Elektronik } & \multicolumn{7}{c}{ Tahun } \\
\cline { 3 - 8 } & & 2015 & 2016 & 2017 & 2018 & 2019 & 2020 \\
\hline 1 & Google Scholar & 44 & 64 & 82 & 87 & 127 & 146 \\
2 & Garuda Ristekbrin & 1 & 1 & 3 & 1 & 0 & 1 \\
3 & Perpustakaan Nasional & 7 & 16 & 2 & 1 & 6 & 2 \\
\hline & TOTAL & 52 & 81 & 87 & 89 & 133 & 149 \\
\hline
\end{tabular}

Sumber: Data Diolah (2021)

Pada tinjauan literatur ini penulis menyeleksi artikel yang ditemukan pada database elektronik tersebut menggunakan beberapa kriteria, di antaranya yaitu: (1) Artikel penelitian asli (bukan merupakan review penelitian), (2) Diterbitkan oleh jurnal/prosiding akuntansi, (3) penelitian dilakukan dalam rentang waktu 20152020, (4) mengkaji tentang kompetensi sumber daya manusia dan pemanfaatan teknologi informasi pada penerapan akuntansi berbasis akrual, serta (5) menyeleksi literatur sehingga tidak ada duplikasi artikel yang akan di-review. Dari kriteria tersebut menghasilkan 37 artikel yang digunakan sebagai sumber literatur dalam studi ini sehingga artikel ini diharapkan dapat memberikan dasar teoritis untuk penelitian masa depan tentang kompetensi sumber daya manusia dan pemanfaatan teknologi informasi dalam penerapan Standar Akuntansi Pemerintahan berbasis akrual dan dapat membantu Pemerintah Pusat maupun Pemerintah Daerah dalam merumuskan tentang bagaimana menerapkan perubahan dan perbaikan dalam pelayanan sektor publik.

Tahapan ketiga yaitu melakukan reporting (pelaporan). Pada tahap ini penulis menuangkan hasil review literatur yang telah dianalisis menggunakan sistematika penulisan yang akan dituliskan dalam sebuah artikel ilmiah. Penulis melakukannya dengan penuh ketelitian dan pemahaman yang mendalam terkait setiap informasi yang ada agar studi ini bisa memberikan manfaat secara maksimal untuk pembaca.

\section{HASIL DAN PEMBAHASAN}

\section{Perubahan Standar Akuntansi Pemerintahan Menggunakan Basis Akrual}

Sesuai dengan amanat bahwa sistem akrual harus diterapkan sebelum tahun anggaran 2008 dalam Undang-Undang Nomor 1 Tahun 2004, dibentuklah Komite Standar Akuntansi Pemerintahan (KSAP) yang memiliki tanggung jawab dalam mempersiapkan perancangan Peraturan Pemerintah tentang Standar Akuntansi Pemerintahan sebagai prinsip akuntansi yang wajib diterapkan dalam penyusunan dan penyajian laporan keuangan Pemerintah Pusat maupun Pemerintah Daerah. KSAP memprakarsai kajian, penelitian, pembahasan dan penyusunan draf standar akuntansi pemerintahan pada tahun 2006. Peraturan Menteri Keuangan (PMK) mengatur SAP berbasis akrual untuk diterapkan pada pemerintah pusat secara bertahap. Sejak tahun 2009, pemerintah pusat mulai menerapkan SAP berbasis 
akrual, dan mulai memberikan informasi akrual pendapatan dan pengeluaran untuk melengkapi laporan Realisasi Anggaran berbasis kas, dengan diterbitkannya Peraturan Pemerintah No. 71 Tahun 2010 tentang Standar Akuntansi Pemerintahan Berbasis Akrual, maka SAP berbasis akrual wajib diterapkan secara penuh paling lambat pada tahun 2015 menggantikan SAP berbasis kas menuju akrual yang ditetapkan dalam Peraturan Pemerintah No. 24 tahun 2005 tentang Standar Akuntansi Pemerintahan berbasis kas menuju akrual (Manossoh, 2015).

\section{Tantangan dalam Penerapan Standar Akuntansi Pemerintahan Berbasis Akrual}

Kesiapan Pemerintah Daerah untuk menerapkan sistem akuntansi pada penyusunan laporan keuangan pemerintahan daerah perlu ditingkatkan sesuai dengan peraturan yang berlaku. Karena basis akuntansi akrual dinilai lebih kompleks, maka dalam beberapa penelitian disebutkan tantangan-tantangan yang dihadapi dalam penerapan SAP berbasis akrual (Mayani et al., 2018). BPK (2015) menyampaikan beberapa tantangan dalam penerapan SAP sistem akrual, yang melibatkan hasil pemeriksaan pada 109 pemerintah daerah di Indonesia, yang menemukan permasalahan terkait kebijakan, sumber daya manusia, dan teknologi informasi dalam penerapan sistem akrual.

\section{Kompetensi Sumber Daya Manusia dalam Penerapan SAP Berbasis Akrual}

Sumber daya manusia merupakan pegawai publik yang terlibat dalam penyusunan laporan keuangan daerah (Saprudin, 2017). Keberhasilan penerapan SAP berbasis akrual bergantung pada tingkat kompetensi yang dimiliki oleh sumber daya manusia, karena penyusunan laporan keuangan yang berkualitas membutuhkan SDM yang memiliki kompetensi yang mumpuni dan memahami peraturan penyusunan laporan keuangan yang berlaku (Erawati \& Kurniawan, 2018). Adanya perubahan basis akuntansi ini pun memerlukan dukungan dari para pimpinan instansi untuk dilaksanakannya sosialisasi dan juga pelatihan yang mumpuni untuk para pegawai atau aparatur. Namun pada awal peralihan basis akuntansi, pelatihan yang mendukung kompetensi sumber daya manusia belum dilaksanakan dengan optimal dan belum memadai (Kristiawati, 2015; Langelo et al., 2015; Erawati \& Kurniawan, 2018).

Penelitian yang dilakukan oleh Asfiansyah (2015), Widyastuti et al. (2015), serta Jantong et al. (2019) menyebutkan bahwa beberapa daerah yang telah melaksanakan pelatihan dan juga bimbingan teknis pun masih ditemukan banyak sekali pegawai yang belum memahami sepenuhnya tentang SAP berbasis akrual. Sumber daya manusia yang tersedia hanya mengetahui tentang definisi dari basis akuntansi akrual dan hanya sebatas informasi saja mengenai pelaksanaan teknis secara penuh akan dimulai pada tahun 2015. SDM yang berhubungan langsung dengan penyusunan laporan keuangan diharapkan mengetahui bagaimana menerapkannya dalam pembuatan laporan keuangan (Satrio et al., 2016).

Hasil penelitian yang dilakukan oleh Fitrizal (2017) menemukan kompetensi SDM juga didukung oleh durasi masa kerja, hal ini dikarenakan masa kerja yang lebih lama dianggap bahwa pegawai tersebut telah melalui dan menyelesaikan berbagai masalah terkait dengan tugas dan tanggung jawabnya dalam pekerjaan yang menjadikan pegawai tersebut lebih ahli dalam bidang pekerjaannya. Hasil 
penelitian tersebut juga menjelaskan bahwa sebagian besar pegawai memahami basis akrual yang digunakan dan hal ini mendukung penerapan perubahan basis akuntansi yang diterapkan. Dari penelitian ini dapat disimpulkan bahwa kualitas sumber daya manusia berpengaruh terhadap keberhasilan penerapan SAP berbasis akrual.

\section{Hambatan Kompetensi Sumber Daya Manusia pada Penerapan SAP Berbasis Akrual}

Hambatan yang dirasakan instansi pemerintahan terkait aspek sumber daya manusia antara lain rendahnya keterampilan pegawai, masa kerja yang sebentar, serta tidak sesuainya latar belakang pendidikan yang dimiliki. Penelitian yang dilakukan oleh Ranuba et al. (2015), Ludfi \& Ahyani (2017), serta Oktaria (2019) menunjukkan SDM yang terdapat pada entitas pemerintah sudah memiliki kesiapan yang baik dan kompetensi yang memadai dalam menerapkan SAP berbasis akrual. Penelitian tersebut pun mengutarakan bahwa kompetensi sumber daya manusia berpengaruh terhadap tingkat keberhasilan penerapan SAP berbasis akrual. Meskipun banyak hasil penelitian yang membuktikan bahwa kompetensi SDM tidak berpengaruh terhadap tingkat keberhasilan penerapan SAP berbasis akrual, antara lain hasil penelitian yang dilakukan oleh Wijayanti \& Handayani (2017), Erawati \& Kurniawan (2018), serta Jantong et al. (2019) yang menyatakan tidak berpengaruhnya kompetensi sumber daya manusia terhadap penerapan SAP berbasis akrual ini disebabkan oleh sosialisasi, pelatihan, dan bimbingan teknis terhadap pegawai belum optimal, bahkan beberapa entitas pemerintahan sama sekali belum melaksanakannya. Namun demikian, kompetensi SDM sejatinya merupakan hal yang krusial dalam penerapan standar akuntansi yang baru ini, karena SAP berbasis akrual bersifat kompleks dan dibutuhkan pemahaman yang baik untuk dapat melakukan pelaporan keuangan sesuai dengan peraturan yang ditetapkan.

Masalah terkait sumber daya manusia pun muncul karena tingkat pendidikan dan latar belakang pendidikan dari pegawai yang bekerja pada bagian keuangan banyak yang tidak berasal akuntansi. Latar belakang pendidikan akuntansi sangat krusial karena SDM yang mendapatkan pendidikan dan pelatihan dengan intensitas yang tinggi, memiliki pengalaman bertugas di bidang keuangan dalam menerapkan sistem akuntansi, serta memiliki latar belakang pendidikan akuntansi, akan memiliki pemahaman yang baik tentang logika akuntansi. SDM yang mengalami kesulitan dalam memahami logika akuntansi akan berpotensi menimbulkan kesalahan pada penyajian laporan keuangan dan ketidaksesuaian laporan keuangan dengan ketentuan yang berlaku (Ramadhani et al., 2019). Penelitian Kristiawati (2015) pun menemukan bahwa sering terjadinya rotasi pegawai, khususnya pegawai akuntansi tanpa melihat kompetensi pemahamannya tentang akuntansi akrual, hal ini berakibat pada pegawai di bidang keuangan tidak diisi oleh sumber daya manusia berkompeten dengan latar belakang pendidikan yang sesuai (Widianti et al., 2016).

Pelatihan yang diadakan untuk menciptakan sumber daya manusia yang kompeten masih mengalami ketimpangan. Penelitian Widianti et al. (2016) mengutarakan bahwa pemahaman pegawai pada instansi publik mengenai sistem akuntansi akrual masih sangat minim. Oleh karena itu, pelatihan dan bimbingan 
teknis tentang akuntansi akrual sebagai bentuk dari kesiapan pemerintah dalam penerapan SAP berbasis akrual sangat dibutuhkan dalam rangka meningkatkan kompetensi pegawai publik. Dengan adanya pelatihan maupun bimbingan teknis mengenai SAP berbasis akrual akan berpengaruh signifikan terhadap keberhasilan penerapan akuntansi akrual di Pemerintahan Daerah (Jantong et al., 2019; Yusrisal, 2020).

Hal ini memberikan bukti bahwa pendidikan dan pelatihan, bimbingan teknis, penempatan sesuai latar belakang pendidikan, serta masa kerja sangat diperlukan agar penerapan SAP berbasis akrual dapat terwujud. Selain itu, walaupun software akuntansi dapat mempermudah penyusunan laporan keuangan sesuai dengan SAP berbasis akrual, jika proses input data tidak dilakukan dengan benar, maka potensi kesalahan tetap dapat terjadi, oleh karena itu sumber daya manusia yang berkompeten tetap memiliki peran yang sangat krusial pada proses ini (Permana \& Wiratmaja, 2016).

\section{Pemanfaatan Teknologi Informasi dalam Penerapan SAP Berbasis Akrual}

Teknologi informasi merupakan salah satu faktor yang berpengaruh terhadap penerapan SAP berbasis akrual (Erawati \& Kurniawan, 2018). Karena dari segi implementasi, waktu pencatatan, dan ruang lingkup, SAP berbasis akrual lebih kompleks dibandingkan dengan SAP berbasis kas. Oleh sebab itu, pemanfaatan teknologi informasi akan berperan dalam meningkatkan efisiensi pada proses pencatatan, proses olah data, penyajian, analisis laporan keuangan (Armel et al., 2017; Karyogis \& Putra, 2017). Salah satu pemanfaatan teknologi informasi adalah adanya aplikasi akuntansi seperti SIMDA, yang dapat mewujudkan pengelolaan keuangan daerah yang terintegrasi, dan penyusunan laporan keuangan akan lebih mudah. Namun SDM yang menggunakan belum sepenuhnya memahami sistem tersebut (Widyastuti et al., 2015; Oktaria, 2019).

Penelitian Fitrizal (2017) menyebutkan bahwa teknologi informasi saling bekerjasama dalam pelaksanaan standar akuntansi pemerintahan di instansi publik. Ketersediaan software, hardware, dan jaringan internet yang memadai ternyata sangat membantu karyawan dalam menyelesaikan tugasnya. Ketersediaan software akuntansi sangat menunjang pengolahan data dan penyusunan laporan keuangan secara efektif dan efisien. Ketersediaan jaringan internet yang memadai juga memudahkan dan mempercepat penyampaian informasi dan pengumpulan data. Hal ini dapat diketahui bahwa pemanfaatan teknologi informasi yang tepat akan sangat membantu penerapan SAP dengan basis akrual secara optimal.

Kualitas teknologi informasi juga ditentukan oleh kualitas pemakai/sumber daya manusia yang menggunakannya (Supra, 2016). Pelatihan untuk sumber daya manusia diperlukan bukan hanya sebatas penerapan akuntansi berbasis akrual, namun juga pelatihan pengoperasian aplikasi akuntansi sebagai pemanfaatan teknologi informasi (Yanni et al., 2020). Karena tingkat keberhasilan pelaksanaan akuntansi akrual akan semakin baik jika teknologi informasi yang ada dimanfaatkan dengan maksimal, dan hal ini dapat dicapai jika pegawai yang mengoperasikan memiliki kompetensi dan pengetahuan dalam menggunakan aplikasi akuntansi (Andhayani, 2017). 


\section{Hambatan Pemanfaatan Teknologi Informasi pada Penerapan SAP Berbasis Akrual}

Beberapa Pemerintah Daerah sudah memiliki kesiapan yang baik dalam bidang teknologi informasi dan pemanfaatannya, hal ini dapat ditemukan pada studi yang dilakukan Ramadhani et al. (2019) yang menyebutkan bahwa tingkat pemanfaatan teknologi informasi pada instansi publik sudah baik, dimana pegawai yang bertugas di OPD Provinsi Banten menggunakan komputer dalam pelaksanaan tugas-tugas dan menggunakan jaringan internet untuk distribusi informasi dengan intensitas yang cukup sering. Hal serupa terdapat pada penelitian oleh Ludfi \& Ahyani (2017) yang menyatakan pemanfaatan teknologi informasi pada Sekretariat Daerah Provinsi Kalimantan Selatan sudah cukup baik. Namun masih terjadi beberapa hambatan dalam pemanfaatan teknologi informasi pada Pemerintah Daerah lainnya pada penerapan SAP berbasis akrual.

Pemanfaatan teknologi informasi diharapkan dapat meningkatkan keberhasilan pada penerapan Standar Akuntansi Pemerintah berbasis akrual. Meskipun beberapa hasil penelitian oleh Widyastuti et al. (2015), Najati \& Pituringsih (2016), serta Ayem \& Saputri (2018) menyebutkan bahwa pemanfaatan teknologi tidak berpengaruh terhadap penerapan Standar Aakuntansi Pemerintahan berbasis akrual, hal ini dapat disebabkan infrastruktur teknologi informasi yang berkualitas masih sangat terbatas. Pemanfaatan teknologi informasi belum dilakukan secara maksimal, serta dana yang dibutuhkan dalam penerapanan teknologi informasi yang cukup banyak, sehingga penerapan teknologi informasi tidak optimal, mahal, dan hasil yang dihasilkan belum dapat dirasakan dengan maksimal dalam waktu dekat.

Berdasarkan hasil studi yang dilakukan oleh Syarienda et al. (2019) pada Pemerintah Daerah Kabupaten Aceh Tengah menyebutkan bahwa hambatan penerapan akuntansi berbasis akrual pada instansi-instansi pemerintahan di antaranya terkait dengan sistem akuntansi dan teknologi informasi, yaitu belum terdapatnya sistem teknologi informasi dan sistem akuntansi yang dapat menunjang ketentuan-ketentuan dalam penerapan akuntansi berbasis akrual. Studi yang dilakukan oleh Supra (2016) pada Pemerintah Daerah Kabupaten Musi Banyuasin yang menyebutkan bahwa jaringan internet belum mumpuni bahkan masih ditemukan beberapa SKPD dengan jaringan internet yang belum terpasang. Masalah serupa pun ditemukan pada studi yang dilakukan oleh Azman (2015) yang menyebutkan tantangan lainnya dalam aspek pemanfaatan teknologi informasi dan komunikasi pada saat peralihan basis akuntansi akrual adalah ketersediaan akses internet yang mumpuni. Dimana koneksi internet belum tersedia pada hampir semua SKPD di Kepulauan Meranti.

Tidak hanya terkait hardware, software, dan jaringan internet, dalam penelitian Alfian (2015) menyebutkan permasalahan terkait pemanfaatan teknologi informasi dalam aspek sumber daya manusia sebagai individu yang mengoperasikan aplikasi akuntansi menemukan bahwa pegawai yang terdapat di SKPD Kabupaten Kulon Progo masih banyak menggunakan software Microsoft Office Excel maupun alat bantu lainnya dibandingkan menggunakan software seperti SIMDA sebagai penunjang dalam menerapkan SAP berbasis akrual pada proses penyusunan laporan keuangan pada pos-pos tertentu, sehingga pemanfaatan software yang menunjang penerapan SAP berbasis akrual tidak optimal. Hal ini 
dapat diatasi dengan pelatihan dan bimbingan teknis yang memadai agar pegawai terbiasa dalam pemakaian software akuntansi penunjang SAP berbasis Akrual.

\section{SIMPULAN}

Standar Akuntansi Pemerintahan berbasis akrual dapat diterapkan secara optimal jika kompetensi dari Sumber Daya Manusia memadai dan pemanfaatan yang optimal dari teknologi informasi. Berdasarkan beberapa studi yang dilakukan, pendidikan dan pelatihan, bimbingan teknis, penempatan sesuai latar belakang pendidikan, serta masa kerja berhubungan langsung dengan tingkat kompetensi SDM. Pemanfaatan teknologi informasi yang tercermin dari tersedianya hardware, software, serta jaringan internet yang mumpuni akan menunjang penerapan SAP berbasis akrual. Hasil studi pun menyebutkan bahwa masih terdapat beberapa Pemerintah Daerah yang belum menyelenggarakan pelatihan dan bimbingan teknis untuk Pegawai Instansi publik dengan optimal dan masih terdapat beberapa kendala dalam pemanfaatan teknologi informasi seperti: jaringan internet yang kurang memadai dan pengguna software yang belum memahami aplikasi secara penuh pada beberapa instansi pemerintah, hal ini dapat diatasi dengan adanya pelatihan dan bimbingan teknis pengoperasian software yang digunakan.

Berdasarkan hasil pembahasan yang telah diuraikan dalam studi literatur ini, diharapkan mampu memberikan implikasi berupa gambaran dan pertimbangan Pemerintah untuk meningkatkan kompetensi sumber daya manusia dan pemanfaatan teknologi informasi secara berkesinambungan dalam penerapan SAP berbasis akrual dengan memaksimalkan penyelenggaraan pendidikan, pelatihan, dan bimbingan teknis, serta penyediaan hardware, software, dan jaringan internet yang memadai. Peneliti menyadari bahwa studi literatur ini masih memiliki beberapa keterbatasan, oleh sebab itu, pada penelitian selanjutnya diharapkan mampu menggunakan metode perhitungan statistik agar lebih menambah keakuratan data untuk mengukur sejauh mana peran kompetensi sumber daya manusia dan pemanfaatan teknologi informasi pada penerapan SAP berbasis akrual. Peneliti selanjutnya juga diharapkan mampu memperdalam penelitian dengan menambah variabel lain seperti: ukuran satuan kerja, motivasi, kesiapan, budaya organisasi, , dan resistensi terhadap perubahan.

\section{DAFTAR PUSTAKA}

Alfian, M. (2015). Faktor Pendukung Implementasi Simda Dan Pengaruhnya Terhadap Kualitas Laporan Keuangan Pada Skpd Kabupaten Kulon Progo. Jurnal Ekonomi Dan Bisnis, 18(3), 119-131.

Andhayani, A. (2017). Dilema Akrualisasi Akuntansi Dalam Pengelolaan Keuangan Daerah. Jurnal Akuntansi Multiparadigma, 8(2), 291-307.

Andiola, L. M., Bedard, J. C., \& Hux, C. T. (2017). Writing a Literature Review In Behavioural Accounting Research. The Routledge Companion to Behavioural Accounting Research, 473-485. https://doi.org/https://doi.org/10.4324/9781315710129-30 
Armaini, R. (2017). Pengaruh Sumber Daya Manusia Dan Teknologi Informasi Terhadap Keberhasilan Penerapan Akuntansi Berbasis Akrual Pada Pemerintah Provinsi Sumatera Selatan. Jurnal ACSY: Jurnal Accounting Politeknik Sekayu, 6(2), 71-86.

Armel, R. Y. G., Nasir, A., \& Safitri, D. (2017). Pengaruh Kompetensi Sumber Daya Manusia, Penerapan Standar Akuntansi Pemerintahan, Pemanfaatan Teknologi Informasi Dan Sistem Pengendalian Internal Terhadap Kualitas Laporan Keuangan Pemerintah Daerah (Studi Pada Satuan Kerja Perangkat Daerah Kota Dumai). JOM Fekon, 4(1), 105-119.

Asfiansyah, A. (2015). Strategi Implementasi Akuntansi Akrual Pada Pemerintah Daerah (Studi Kasus Pada Pemerintah Kota "S"). Neo-Bis, 9(1), 1-19.

Ayem, S., \& Saputri, N. F. (2018). Komunikasi Organisasi Vertikal Sebagai Pemoderasi Pengaruh Kualitas Sumber Daya Manusia, Budaya Organisasi Dan Teknologi Informasi Pada Penerapan Standar Akuntansi Pemerintahan Berbasis Akrual (Studi Kasus Pada Badan Keuangan Dan Aset Daerah Kabupaten Kul. Jurnal Akuntansi, 6(2), 165-179.

Azman, T. (2015). Analisis Komitmen Organisasi, Kesiapan Sumberdaya Manusia, Infrastruktur Serta Sistem Informasi Dalam Menerapkan Standar Akuntansi Pemerintah Berbasis Akrual. Sorot, 10(1), 131-142.

Badan Pemeriksa Keuangan. (2015). Pendapat BPK Kesiapan Pemerintah Dalam Pelaporan Keuangan Berbasis Akrual Tahun 2015. BPK-RI. Jakarta. Nur Mayani, A. Faroby Falatehan Strategi Peningkatan Kesiapan Sumber Daya Manusia.

Binawati, E., \& Susliyanti, E. D. (2020). Pengaruh Kualitas Teknologi Informasi Dan Kompetensi Sumber Daya Manusia Terhadap Kualitas Laporan Keuangan Yang Dimoderasi Dengan Penerapan Standar Akuntansi Pemerintah (Sap) Berbasis Akrual Dan Sistem Akuntansi Keuangan Pemerintah. Jurnal Optimal, 17(2), 20-37.

Budiono, A. (2016). Penerapan Standar Akuntansi Persediaan Berbasis Akrual Pada Pemerintah Kota Tangerang Tahun 2015. Tesis, Jakarta, STIA LAN.

Dewi, L. D. S., Purnamawati, I. G. A., \& Herawati, N. T. (2017). Pengaruh Kualitas Sumber Daya Manusia, Komitmen Organisasi, dan Sistem Pengendalian Intern terhadap Keberhasilan Penerapan SAP Berbasis Akrual (Studi Empiris pada SKPD Kabupaten Bangli). JIMAT (Jurnal Ilmiah Mahasiswa Akuntansi) Undiksha, 7(1).

Dewi, L. K. U., Yuniarta, G. A., Ak, S. E., \& Prayudi, M. A. (2018). Pengaruh Kualitas Sumber Daya Manusia, Komitmen Organisasi, Dan Pemanfaatan Sistem Informasi Akuntansi Keuangan Daerah Terhadap Keberhasilan Penerapan Sap Berbasis Akrual (Studi Empiris Pada Skpd Kabupaten Badung). JIMAT (Jurnal Ilmiah Mahasiswa Akuntansi) Undiksha, 8(2).

Erawati, T., \& Kurniawan, D. (2018). Penerapan Sistem Akuntansi Berbasis Akrual: Kajian Dari Aspek Keperilakuan. Jurnal Ekonomi Dan Bisnis, 21(2), 313-332.

Fitrizal, R. (2017). Pengaruh Kualitas Sumber Daya Manusia, Sistem Informasi, dan Komitmen Organisasi terhadap Implementasi Sistem Akuntansi Pemerintah Berbasis Akrual (Studi Empiris pada SKPD Kabupaten Pesisir Selatan). Jurnal Akuntansi, 5(1).

Hastutik, P., \& Riduwan, A. (2018). Pengaruh Kompetensi Sumber Daya Manusia Dan 
Akuntansi Akrual Terhadap Kualitas Laporan Keuangan Daerah. Jurnal Ilmu Dan Riset Akuntansi, 7(7).

Indrawati, L. (2018). Faktor-faktor yang Mempengaruhi Keberhasilan Penerapan Akuntansi Berbasis Akrual pada Satuan Kerja Politeknik Negeri Bandung. Ekspansi: Jurnal Ekonomi, Keuangan, Perbankan Dan Akuntansi, 10(1), 1-11.

Iznillah, M. L., Silfi, A., \& Azlina, N. (2015). Pengaruh Kualitas Sumber Daya Manusia, Komitmen Organisasi, Teknologi Informasi, dan Komunikasi terhadap Kesiapan Pemerintah dalam Menerapkan Standar Akuntansi Pemerintah Berbasis Akrual (Studi Empiris pada Pemerintah Kabupaten Indragiri Hilir). Jom FEKON, 2(2).

Jantong, A., Nurkholis, N., \& Roekhudin, R. (2019). Faktor-Faktor Yang Mempengaruhi Kesiapan Penerapan Standar Akuntansi Pemerintahan Berbasis Akrual Pada Pemerintahan Daerah. Jurnal Bisnis Dan Manajemen, $5(2)$.

Karyogis, K. N., \& Putra, I. P. D. (2017). Analisis Faktor-Faktor Yang Mempengaruhi Penerapan Standar Akuntansi Pemerintahan Berbasis Akrual Di Kabupaten Bangli. E-Jurnal Akuntansi, 20(1), 555-584.

Kristiawati, E. (2015). Faktor-Faktor Yang Mempengaruhi Keberhasilan Penerapan Akuntansi Berbasis Akrual Pada Pemerintahan Daerah Kalimantan Barat. Akuntabilitas, 8(3), 171-190.

Langelo, F., Saerang, D. P. E., \& Alexander, S. W. (2015). Analisis Penerapan Standar Akuntansi Pemerintahan Berbasis Akrual Dalam Penyajian Laporan Keuangan Pada Pemerintah Kota Bitung. Jurnal EMBA: Jurnal Riset Ekonomi, Manajemen, Bisnis Dan Akuntansi, 3(1).

Ludfi, R., \& Ahyani, H. (2017). Analisis Kualitas Sumber Daya Manusia Dan Sistem Teknologi Informasi Terhadap Keberhasilan Penerapan Standar Akuntansi Pemerintahan (SAP) Berbasis Akrual. Jurnal Spread, 7.

Manossoh, H. (2015). Implementasi Sistem Akuntansi Pemerintahan Dalam Mewujudkan Good Government Governance Pada Pemerintah Provinsi Sulawesi Utara. Jurnal Berkala Ilmiah Efisiensi, 15(5).

Massaro, M., Dumay, J., \& Guthrie, J. (2016). On the shoulders of giants: undertaking a structured literature review in accounting. Accounting, Auditing \& Accountability Journal, 29(5), 767-801. https://doi.org/https://doi.org/10.1108/AAAJ-01-2015-1939

Mayani, N., Falatehan, A. F., \& Wahyuni, E. S. (2018). Strategi Peningkatan Kesiapan Sumber Daya Manusia dalam Implementasi Akuntansi Berbasis Akrual di Pemerintah Kabupaten Kepulauan Selayar. Jurnal Manajemen Pembangunan Daerah, 10(1), 67-81.

Najati, I., \& Pituringsih, E. (2016). Implementasi Akuntansi Berbasis Akrual: Pengujian Determinan dan Implikasinya terhadap kualitas laporan keuangan kementerian/lembaga. Lembaga Jurnal Akuntansi Universitas Jember, 14(1).

Niagawan, K. A. R., Yuliantari, N. P. Y., \& Pratiwi, N. P. T. W. (2020). Pengaruh Kompetensi Sumber Daya Manusia, Sistem Informasi, Dan Kualitas Teknologi Informasi Terhadap Penerapan Standar Akuntansi Pemerintah Berbasis Akrual. Hita Akuntansi Dan Keuangan, 1(2), 130-159.

Oktaria, M. (2019). Pengaruh Kompetensi Aparatur, Pemanfaatan Teknologi Informasi Dan Komitmen Organisasi Terhadap Penerapan Akuntansi 
Berbasis Akrual (Studi Pada Pemda Kabupaten/Kota Dan Provinsi Yang Ada Di Wilayah Provinsi Kalimantan Tengah). Riset Akuntansi Dan Perbankan, 13(2), 181-199.

Pattiasina, V., \& Noch, M. Y. (2019). Implementasi Akuntansi Berbasis Akrual Ditinjau Dari Sisi Sumber Daya Manusia, Pemanfaatan Teknologi Informasi Dan Sistim Pengendalian Intern. AccJu-Accounting Journal, 1(01), 18-28.

Permana, I. B. G. B., \& Wiratmaja, I. D. N. (2016). Pengaruh Sumber Daya Manusia, Komitmen Organisasi, Sistem Informasi Pada Kesiapan Penerapan Laporan Keuangan Pemerintah Daerah Berbasis Akrual. E-Jurnal Akuntansi, 16(3), 2260-2287.

Putra, I. W. G. Y. D., \& Ariyanto, D. (2015). Faktor-Faktor Yang Mempengaruhi Penerapan Standar Akuntansi Pemerintahan Berbasis Akrual. E-Jurnal Akuntansi, 13(1), 14-32.

Ramadhani, M., Soerono, A. N., \& Mulyasari, W. (2019). Pengaruh Sumber Daya Manusia, Sistem Pengendalian Intern, Teknologi Informasi, dan Pemahaman Basis Akrual Terhadap Kualitas Laporan Keuangan Pemerintah Daerah (Studi Pada Organisasi Perangkat Daerah Provinsi Banten). Jurnal Riset Akuntansi Terpadu, 12(1).

Ranuba, E. D. S., Pangemanan, S., \& Pinatik, S. (2015). Analisis Kesiapan Penerapan Standar Akuntansi Pemerintah Berbasis Akrual Berdasarkan PP No. 71 Tahun 2010 Pada DPKPA Minahasa Selatan. Jurnal EMBA: Jurnal Riset Ekonomi, Manajemen, Bisnis Dan Akuntansi, 3(1).

Peraturan Pemerintah Nomor 101 Tahun 2000, Pendidikan dan Pelatihan Jabatan Pegawai Negeri Sipil.

Peraturan Pemerintah Nomor 71 Tahun 2010, Standar Akuntansi Pemerintahan Berbasis Akrual.

Santis, S., Grossi, G., \& Bisogno, M. (2018). Public Sector Consolidated Financial Statements: A Structured Literature Review. Journal of Public Budgeting, Accounting \& Financial Management, 30(2), 230-251. https://doi.org/10.1108/JPBAFM-02-2018-0017

Saprudin, S. (2017). Kesiapan Pemerintah Daerah dalam Penerapan Standar Akuntansi Pemerintahan Berbasis Akrual (Studi Kasus Pada Badan Keuangan Provinsi Gorontalo). Ekuitas: Jurnal Pendidikan Ekonomi, 5(2), 59-69.

Sari, F. H., Suprasto, B., \& Dwirandra, A. (2016). Motivasi Sebagai Pemoderasi Pengaruh Kompetensi Dan Teknologi Informasi Pada Penerapan Akuntansi Berbasis Akrual. E-Jurnal Ekonomi Dan Bisnis Universitas Udayana.

Satrio, M. D., Yuhertiana, I., \& Hamzah, A. (2016). Implementasi Standar Akuntansi Pemerintah Berbasis Akrual di Kabupaten Jombang. Jurnal Akuntansi Dan Keuangan, 18(1), 59-70. https://doi.org/10.9744/jak.18.1.59-70

Sinaga, J. (2005). Selamat Datang Standar Akuntansi Pemerintahan. Jurnal Akuntansi Pemerintah, 1(2), 1-8.

Supra, D. (2016). Pengaruh Tingkat Pendidikan, Pelatihan, dan Kualitas Teknologi Informasi terhadap Penerapan Standar Akuntansi Pemerintahan Berbasis Akrual pada Pemerintah Kabupaten Musi Banyuasin. Jurnal ACSY: Jurnal Accounting Politeknik Sekayu, 5(2), 9-23.

Syarienda, Y., Basri, H., \& Fahlevi, H. (2019). Problematika Penerapan Akuntansi Berbasis Akrual Pada Pemerintah Daerah Aceh Tengah. Jurnal Perspektif 
Ekonomi Darussalam, https://doi.org/10.24815/jped.v4i1.10923

Ternalemta, T., Kalangi, L., \& Tinangon, J. J. (2021). Pengaruh Kompetensi Sumber Daya Manusia, Penerapan Akuntansi Berbasis Akrual, Sistem Pengendalian Internal Pemerintah Dan Pemanfaatan Teknologi Informasi Terhadap Kualitas Laporan Keuangan. Jurnal Riset Akuntansi Dan Auditing " GOODWILL,"12(1), 38-50.

Usman, R., Misra, F., \& Firdaus. (2019). Pengaruh Kekayaan Daerah dan Belanja Modal Terhadap Kinerja Penyelanggaraan Pemerintah: Pengujian Legislative Power Sebagai Variabel Pemoderasi. E-Journal Akuntansi, 29(2), 561-576.

Wardani, D. K., \& Andriyani, I. (2017). Pengaruh Kualitas Sumber Daya Manusia, Pemanfaatan Teknologi Informasi, Dan Sistem Pengendalian Intern Terhadap Keandalan Pelaporan Keuangan Pemerintahan Desa Di Kabupaten Klaten. Jurnal Akuntansi, 5(2), 88-98.

Widianti, H., Hadiyati, S. N., \& Sulistyowati, D. (2016). Analisis Faktor-faktor Yang Mempengaruhi Implementasi Akuntansi Akrual Pada Sektor Pemerintah. Prosiding Seminar Nasional IPTEK Terapan (SENIT) 2016 Pengembangan Sumber Daya Lokal Berbasis IPTEK, 1(1).

Widyastuti, N. M. A., Sujana, E., \& Adiputra, I. M. P. (2015). Analisis Kesiapan Pemerintah Daerah Dalam Menerapkan Standar Akuntansi Pemerintahan Berbasis Akrual Di Kabupaten Gianyar. JIMAT (Jurnal Ilmiah Mahasiswa Akuntansi) Undiksha, 3(1).

Wijayanti, R., \& Handayani, N. (2017). Pengaruh Kompetensi SDM Dan Implementasi Akuntansi Akrual Terhadap Kualitas Laporan Keuangan Daerah. Jurnal Ilmu Dan Riset Akuntansi (JIRA), 6(3).

Yanni, Y., Randa, F., \& Bangun, Y. K. (2020). Pemaknaan Penerapan Akuntansi Basis Akrual (Studi Pada Pemerintahan Kabupaten Toraja Utara). AJAR, 3(01), 4867.

Yuhertiana, I. (2015). Behavioural public sector accounting research in Indonesia: a literature review. Malaysian Accounting Review, 14(1), 50-64.

Yusrisal, H. (2020). Analisis Faktor-Faktor Yang Mempengaruhi Implementasi Akuntansi Akrual Pada Unit Satuan Kerja Kantor Camat Pangean Kabupaten Kuantan Singingi. JUHANPERAK, 1(2), 645-663.

Zhu, M., Sari, A., \& Lee, M. M. (2018). A Systematic Review Of Research Methods And Topics Of The Empirical Mooc Literature (2014-2016). The Internet and Higher Education, 37, 31-39. https://doi.org/10.1016/j.iheduc.2018.01.002 
EQUITY, Vol. 24, No.2, 2021, 141-156

Halaman ini sengaja dikosongkan untuk kepentingan penggenapan halaman 